\title{
Antioxidant Capacity and Cytotoxicity of the Aqueous Extract of Myrcia guianensis (Aubl.) DC
}

\author{
Regiane Sablina Almeida Bernardes ${ }^{1,2}$, Sandra Layse Ferreira Sarrazin², Flaviana Alves dos Santos ${ }^{4}$, Moacyr \\ Jesus Barreto de Melo Rêgo ${ }^{4}$, Maira Galdino da Rocha Pitta ${ }^{4}$, Marina Ferraz Cordeiro ${ }^{5}$, Patrícia Danielle Oliveira \\ de Almeida ${ }^{6}$, Ricardo Bezerra de Oliveira² ${ }^{2}$ Leoneide Érica Maduro Bouillet ${ }^{2}$, José Guilherme Soares Maia ${ }^{3}$, Rosa \\ Helena Veras Mourão ${ }^{1,2,3 *}$
}

\begin{abstract}
Regiane Sablina Almeida Bernardes ${ }^{1,2}$, Sandra Layse Ferreira Sarrazin², Flaviana Alves dos Santos ${ }^{4}$, Moacyr Jesus Barreto de Melo Rêgo ${ }^{4}$, Maira Galdino da Rocha Pitta ${ }^{4}$, Marina Ferraz Cordeiro ${ }^{5}$, Patrícia Danielle Oliveira de Almeida ${ }^{6}$, Ricardo Bezerra de Oliveira ${ }^{2}$, Leoneide Érica Maduro Bouillet ${ }^{2}$, José Guilherme Soares Maia ${ }^{3}$, Rosa Helena Veras Mourão ${ }^{1,2,3 *}$
\end{abstract}

'Programa de Pós-Graduação em Biodiversidade e Biotecnologia da Amazônia Legal (Bionorte), Universidade Federal do Amazonas, 60077-000 Manaus, AM, BRAZIL.

${ }^{2}$ Laboratório de Bioprospecção e

Biologia Experimental, Universidade Federal do Oeste do Pará, 68135-110 Santarém, PA, BRAZIL.

3Programa de Pós-Graduação em Recursos Naturais da Amazônia, Universidade Federal do Oeste do Pará, 68135-110 Santarém, PA, BRAZIL.

${ }^{4}$ Núcleo de Pesquisa para Inovação Terapêutica Suely Galdino,

Universidade Federal de Pernambuco, 50670901 Recife, PE, BRAZIL.

${ }^{5}$ Universidade Federal do Vale do São Francisco, Colegiado de Medicina, Campus Paulo Afonso, 48607-190, BA, BRAZIL.

${ }^{6}$ Universidade Federal do Amazonas, Laboratório de Atividade Biológica, 60077-000 Manaus, AM, BRAZIL.

\section{Correspondence}

\section{Dr. Rosa Helena V. Mourão}

Universidade Federal do Oeste do Pará, Laboratório de Bioprospecção e Biologia Experimental, 68135-110 Santarém, PA, BRAZIL.

Phone no : +55 93 99122-3301

E-mail: rosa.mourao@ufopa.br

\section{History}

- Submission Date: 02-05-2018.

- Review completed: 28-06-2018;

- Accepted Date: 04-10-2018

DOI : 10.5530/pj.2018.6s.25

Article Available online

http://www.phcogj.com/v10/i6s

\section{Copyright}

(C) 2018 Phcog.Net. This is an openaccess article distributed under the terms of the Creative Commons Attribution 4.0 International license.

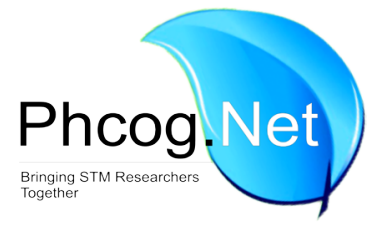

\begin{abstract}
Introduction: Ethnobotanical studies report that Myrcia guianensis (Myrtaceae), belonging to a group of plants known as pedrá-ume-caá or insulin plant, is used as a tea to treat various diseases, including diabetes, a metabolic disorder that leads to the constant production of free radicals. The objective of this work was to determine the antioxidant capacity and the cytotoxicity of the AEMg. Methods: The content of phenolic compounds in AEMg was determined by colorimetric assays. In vitro tests of the antioxidant capacity of AEMg, in the sequestration of DPPH radicals, in $\beta$-carotene bleaching, in the FRAP, as well as in human fibroblast cells of the MRC-5 lineage, were performed. The cytotoxic activity of AEMg was evaluated in assays with eukaryotic cells from yeast Saccharomyces cerevisiae and in PBMC. Results: The results showed that the AEMg is rich in phenolic compounds, presenting high antioxidant potential in all the tests carried out, including in human fibroblast cells of the MRC-5 lineage, besides not being toxic to eukaryotic cells. Conclusion: The AEMg, rich in antioxidant compounds and no toxicity, can be used as source of natural antioxidant in the treatment of metabolic diseases to combat free radicals.
\end{abstract}

Key words: Antioxidant activity, Myrtaceae, Oxidative Stress, Pedra-ume-caá, Phenolic Compounds.

\section{INTRODUCTION}

Myrtaceae Juss. Comprises 132 genera and 5671 species of trees and shrubs, which are distributed mainly in tropical and subtropical regions of the world, particularly South America, Australia and Tropical Asia. ${ }^{1}$ It is one of the most prominent families in Brazil, represented by 23 genera and 1034 species, with occurrence in all regions of the country ${ }^{2-3}$ Myrcia De Candolle is one of the largest genera in the Americas, with more than 300 species distributed from Mexico to Southern Brazil, occurring in its different biomes, especially in savannas and secondary forests. ${ }^{4}$

Myrcia guianensis (Aubl.) DC. has an extensive synonymy with species and varieties of Aulomyrcia, Eugenia, Myrcia and Myrtus. ${ }^{5}$ It is a medium-sized shrub widely distributed in the Brazilian Amazon and included in a group of species of Myrcia, popularly known as "Pedra-ume-caá" or "Insulin plant". Some studies have demonstrated the widespread use of Myrcia species as hypoglycemic agents, such as M. multiflora ${ }^{6-7}$ M. bella ${ }^{8}$ and $M$. splendens and M. palustris. ${ }^{9-10}$ Also, the macerated leaves of M. guianensis have been used to neutralize various snake venoms effects. ${ }^{11}$ The hydroalcoholic leaf extract of M. guianensis was analized by HPLCPDA-ESI/MS, showing the presence of gallic, caffeic and quinic acids, in addition to other glycosylated flavonoid derivatives. ${ }^{12}$ Gallic and protocatechuic acids were previously identified in the ethyl acetate leaf extract of $M$. guianensis. ${ }^{13}$ Phenolic acids and glycosylated flavonoid derivatives from myricetin and quercetin were also found in the $70 \% \mathrm{EtOH}$ extract of $M$. bella. ${ }^{8,14} \mathrm{~A}$ review of the constituents and the pharmacological activities of Myrcia was reported, where many information about its uses were included. ${ }^{15}$

The oxidative process resulting from normal cell metabolism continuously produces ROS or free radicals. In equilibrium conditions between the production of ROS and the endogenous antioxidant defenses, these radicals are beneficial, performing several essential biological functions for the human organism. However, under imbalance conditions these radicals cause deleterious effects to the membranes, proteins, mitochondria and DNA molecules, causing alterations in the structures and the cellular functions. ${ }^{16}$ It is in this sense that the study of free radicals has increased considerably in recent years and the discovery of its deleterious effects, as well as its relation with certain diseases, have been driving the search for new molecules that can prevent or minimize the oxidative damage to the living cells. 
In this context, plants appear as alternative and promising natural sources of new antioxidant compounds and this effect is mainly related to the presence of phenolic compounds that act as reducing agents, exerting protection to the body against oxidative stress in diseases such as diabetes, cancer and Alzheimer's disease. ${ }^{17-18}$

Considering the traditional use of M. guianensis as a hypoglycemic and antihemorrhagic agent, as well as due to the presence of phenolic compounds in the organic extracts of its leaves, the present study was conducted with the purpose of investigating the antioxidant capacity and cytotoxicity the aqueous extract of $M$. guianensis leaves.

\section{MATERIALS AND METHODS}

\section{Plant material and processing}

Leaves of M. guianensis were collected in May 2014 (rainy season), in the city of Santarém, PA, Brazil, coordinates $02^{\circ} 25^{\prime} 12.3^{\prime \prime}$ S / 54 $44^{\circ} 23.3^{\prime \prime}$ W. Plant was identified and deposited in the herbarium of the INPA, Manaus, AM, Brazil, under number 258.148. After washing and drying ( 4 days, $25^{\circ} \mathrm{C}$ ) the leaves were powdered and the resulting plant drug was subjected to determination of their granulometry, swelling index, water percentage, density, $\mathrm{pH}$ and total ashes. ${ }^{19}$

Two aqueous extracts (at $25^{\circ} \mathrm{C}$ and $70^{\circ} \mathrm{C}$ ) and two hydroalcoholic extracts (at 60\% and 70\%) were tested to evaluate the best extraction method of the phenolic compounds (total tannins, total phenols and flavonoids). The plant drug powdered $(100 \mathrm{mg} / \mathrm{mL})$, solubilized in distilled water and ethanol (95\%, v/v, Vetec) and was used to obtain these extracts. After homogenization, the corresponding solutions were sonicated $(30 \mathrm{~min}$, $25^{\circ} \mathrm{C}$, BRANSON 3510 ) and filtered (quantitative filter paper, Unifil $85 \mathrm{~g}$, $0,2 \mathrm{~mm}$ ). The extracts were tested for phenolic compounds according to the methodologies selected and described below. The best result was with the aqueous extract elaborated at $70^{\circ} \mathrm{C}$. Thus, the AEMg was prepared with $150 \mathrm{~g}$ of the plant drug in $750 \mathrm{ml}$ of distilled water. The mixture was kept under digestion $\left(70 \pm 5^{\circ} \mathrm{C}\right)$ with constant stirring $(30 \mathrm{~min})$ and then filtered, frozen, lyophilized (LIOTOP L101) and used in the assays.

\section{Phenolic compounds determination}

Total phenolics, tannins and flavonoids were determined by the traditional spectrophotometric methods (SPECTROPHOTOMETER, NOVA 3300UV) using bovine serum albumin (protein standard, Sigma-Aldrich) and the reagents ferric chloride (Sigma-Aldrich) and aluminum chloride (Sigma-Aldrich). ${ }^{20-21}$ The results were expressed in grams of tannic acid (Sigma-Aldrich) equivalent (gTAE/100g) for total phenolics and tannins and rutin equivalent (gRE/100g) for total flavonoids. All analyzes were performed in triplicate.

\section{Antioxidant capacity of the aqueous extract of $M$. guianensis}

\section{DPPH radical scavenging assay}

The antioxidant capacity of AEMg was determined by the DPPH (Sigma-Aldrich) radical scavenging assay, according to Miliauskas and coauthors. ${ }^{22} \mathrm{AEMg}$ was tested at the concentrations of 1, 2, 5, 10, 20 and $30 \mu \mathrm{g} / \mathrm{mL}$ and ethanol (Vetec) and Trolox (Sigma-Aldrich) were used as the control and antioxidant standard, respectively. The absorbance was measured at $517 \mathrm{~nm}$ (SPECTROPHOTOMETER, NOVA $3300 \mathrm{UV}$ ), between 5 and $90 \mathrm{~min}$, to determine the time required to stabilize the reaction. The antioxidant activity was expressed as percent inhibition (I \%), according to the equation, $\mathrm{I}=(\mathrm{Ac}-\mathrm{As}) / \mathrm{Ac} \times 100$, where the absorbance of the control is Ac and the absorbance of the sample is As. The sample concentrations and inhibition percentages were subjected to linear regression analysis to determine the $\mathrm{IC}_{50}$ values. The assay was performed in triplicate.

\section{$\beta$-Carotene/linoleic acid assay}

The AEMg ability to inhibit the $\beta$-carotene bleaching was evaluated according to Koleva and colleagues (2002). ${ }^{23}$ The reaction mixture was prepared with $\beta$-carotene ( $1.0 \mathrm{mg}$, Sigma-Aldrich) dissolved in chloroform ( $5 \mathrm{~mL}$, Sigma-Aldrich). After evaporation of the chloroform, distilled water $(50 \mathrm{~mL}$, saturated with oxygen) was added and $1.0 \mathrm{~mL}$ of the solution was mixed with linoleic acid $(20 \mu \mathrm{L}$, Sigma-Aldrich $)$ and Tween $40(265 \mu \mathrm{L}$, Sigma-Aldrich). Aliquots of AEMg $(200 \mu \mathrm{L}, 4.0 \mathrm{mg} / \mathrm{mL})$, solubilized in a mixture of water: ethanol $(1: 5 \mathrm{v} / \mathrm{v}$, Vetec $)$ plus Trolox $(1.0 \mathrm{mg} / \mathrm{mL}$, Sigma-Aldric), were added to the solution of $\beta$-carotene/linoleic acid $(2500 \mu \mathrm{L})$. The measurements were taken immediately (time zero) at the absorbance of $470 \mathrm{~nm}$ (SPECTROPHOTOMETER, NOVA $3300 \mathrm{UV}$ and the solutions were incubated in a water bath $\left(50^{\circ} \mathrm{C}\right)$. Then, new measurements were made for $120 \mathrm{~min}$, with intervals of $15 \mathrm{~min}$ each. The AEMg ability to protect the lipid substrate from oxidation was expressed as percent inhibition (I \%), calculated about the decay of the absorbance of the control and the sample, during the $120 \mathrm{~min}$ of the reaction. It was conducted according to the equation I: (Ac - Aa) / Ac x 100 where the absorbance of the control is Ac and the absorbance of the sample is Aa. The assay was performed in triplicate.

\section{FRAP assay}

FRAP assay was conducted according to Pishoschi and Negulescu (2011). ${ }^{24} 90 \mu \mathrm{L}$ of the ferrous sulfate solution (2.0 mM, Sigma-Aldrich), $270 \mu \mathrm{L}$ of distilled water and $2.7 \mathrm{~mL}$ of the FRAP reagent $(25 \mathrm{~mL}$ acetate buffer, $0.3 \mathrm{M}$, pH 3.6, Sigma-Aldrich), $2.5 \mathrm{~mL}$ of solution TPTZ (10 mM, Sigma-Aldrich) and $2.5 \mathrm{~mL}$ of ferric chloride aqueous solution $(20 \mathrm{mM}$, Sigma-Aldrich). The mixture was homogenized, kept in a water bath $\left(37^{\circ} \mathrm{C}, 30 \mathrm{~min}\right)$ and the absorbance was measured at $595 \mathrm{~nm}$ (SPECTROPHOTOMETER, NOVA $3300 \mathrm{UV})$. A stock solution of AEMg $(4.0 \mathrm{mg} / \mathrm{mL})$ at concentrations $31,62,125,250,375$ and $500 \mu \mathrm{g} / \mathrm{mL}$ was used for the assay and the Trolox standard curve ( $2 \mathrm{mM}$, Sigma-Aldrich). The assay was performed in triplicate.

\section{Human cell culture assay}

The human fibroblast cell line MRC-5 was obtained from the Rio de Janeiro Cell Bank, Brazil, maintained in a DMEM and supplemented with 10\% FBS (GIBCO), penicillin (100 U/mL, GIBCO) and streptomycin $(100 \mathrm{U} / \mathrm{mL})$. The cells were incubated at $37^{\circ} \mathrm{C}$ in a humid $5 \% \mathrm{CO}_{2}$ atmosphere, as described by Wolfe and Liu (2007). ${ }^{25}$ MRC-5 cells were plated at a density of $6 \times 10^{4}$ cells/well in $100 \mu \mathrm{L}$ of growth medium, in a 96 well microplate. The medium was removed after $24 \mathrm{~h}$ and the wells washed with PBS. A DCFDA solution $(10 \mu \mathrm{M})$ dissolved in Hank's buffer $(100 \mu \mathrm{L})$ was added and the cells were incubated at $37^{\circ} \mathrm{C}(30 \mathrm{~min})$ in a $5 \%$ $\mathrm{CO}_{2}$ atmosphere. Then, the cells were washed in PBS $(100 \mu \mathrm{L})$ and the AEMg samples at different concentrations $(1,2,5,10,20$ and $30 \mu \mathrm{g} / \mathrm{mL})$ were added. Fluorescence was read immediately at an excitation wavelength of $485 \mathrm{~nm}$ and an emission wavelength of $520 \mathrm{~nm}$ for $120 \mathrm{~min}$, at intervals of $5 \mathrm{~min}$. The controls, with and without DCFDA, were prepared and subjected to the same procedure. Quercetin (Sigma-Aldrich) was used as a positive control.

\section{Cytotoxicity in eukaryotic cells Saccharomyces cerevisiae cells}

S. cerevisiae, $\Delta \mathrm{ycf1}$ strain (YDR1356, mutant carrying deficiency in the antioxidant defense system), were used as an experimental model to analyze the cytotoxicity of AEMg in eukaryotic cells. Yeasts were donated by Dr. Daniel Brèthes (Institut de Biochimie et Génétique Cellulaire, France) and Dr. Jean Paul Bordineaux (Université de Bordeaux, France). Yeasts were maintained in YPD culture medium (Yeast extract 10g/L, Peptone 20g/L, Dextrose 20g/L and Agar 15g/L, DIFCO). Cells 
obtained from the isolated colonies were distributed in Flacon tubes and initial $\mathrm{OD}_{595}=0.6$ (MICROPLATE READER 680) and added with AEMg $(20 \mu \mathrm{L})$, giving the final concentrations of $50,250,500$ and $750 \mathrm{mg} / \mathrm{mL}$. Cadminum chloride $\left(\mathrm{CdCl}_{2}, 20 \mu \mathrm{M}\right.$, Sigma) was used as a cytotoxic agent. The cultures were transfered to 96-weel microplates and kept at $27^{\circ} \pm 2$ under constant agitation of $225 \mathrm{rpm}$ (BIOST 604). The treatments were kept under the same conditions above, for $6 \mathrm{~h}$ and the optical density $\left(\mathrm{OD}_{595}\right)$ was measured in a microplate reader at $0,3 \mathrm{~h}, 4 \mathrm{~h}, 5 \mathrm{~h}$ and $6 \mathrm{~h}{ }^{26}$

\section{Peripheral blood mononuclear cells}

PBMC were obtained from heparinized blood from healthy, non-smoking donors who had not taken any drugs for at least 15 days before sampling $(n=4)$. PBMC were isolated by a standard method of density-gradient centrifugation over Ficoll-Hypaque (15 mL, GE HEALTHCARE). Cells were counted in a Neubauer chamber and viability was determined by the trypan blue exclusion method. Cells were only used when viability was $>98 \%$. All donors signed an informed consent form and the study was approved by the Human Research Ethics Committee of Universidade Federal de Pernambuco, Centro de Ciências da Saúde (CEP/CCS/UFPE No. 46976315.9.00005208), Recife, Brazil. Cells were plated in 96-well plates $\left(10^{6}\right.$ cells/well). After $24 \mathrm{~h}$ the $\operatorname{AEMg}(1,10,50,100$ and $200 \mu \mathrm{g} / \mathrm{mL})$ was added and plates were incubated for $48 \mathrm{~h}$. Cell viability was determined by the ability to live cells to reduce the yellow dye MTT $(20 \mathrm{~mL}$, $0.5 \mathrm{mg} / \mathrm{mL}$, Sigma-Aldric) to a blue formazan product, after the addition of MTT in each well. Cells were reincubated $(3 \mathrm{~h})$, the blue formazan precipitate was dissolved in $20 \%$ SDS, Sigma-Aldrich) and its absorbance measured at $570 \mathrm{~nm}$, using a plate reader (EL808; BIOTEK) ${ }^{27}$

\section{Statistical analysis}

The results were expressed as mean \pm standard deviation. The means were compared by one-way or two-way analysis of variance (ANOVA) followed by Tukey's post-test (for multiple comparisons). A significance level of $p \leq 0.05$ was used (software GraphPad Prism 6). IC $_{50}$ values were obtained by nonlinear regression with the OriginPro program (8.0, OriginLab, Northampton, Massachusetts, USA), with $95 \%$ confidence intervals.

\section{RESULTS}

\section{Characterization of the plant drug and quantification of phenolic compounds}

The physicochemical parameters associated with the characterization of the plant drug and the AEMg are presented in Table 1. The results are within limits established by the Brazilian Pharmacopoeia (2010). ${ }^{19}$ Also, these results evidenced good practices in the production of M. guianensis plant material.

Table 1: Plant drug characterization of $M$. guianensis and its derivatives.

\begin{tabular}{ccc}
\hline Samples & Parameters & Results \\
\hline PD & Intumescence $(\mathrm{mL} / \mathrm{g})$ & $4.3 \pm 0.28$ \\
PD & Moisture content (\%) & $10.08 \pm 0.2$ \\
PD & Total ash (\%) & $5.85 \pm 0.16$ \\
PD & Particle size & Powder, thick \\
AEMg & Yield (\%) & 21.03 \\
AEMg & pH & 4.29 \\
LAEMg & Residue, dry (\%) & $90.48 \pm 0.10$ \\
\hline
\end{tabular}

PD: plant drug; AEMg: aqueous extract of M. guianensis; LAEMg: lyophilized aqueous extract of $M$. guianensis. Results expressed as mean \pm standard deviation $(n=3)$.
Table 2: Phenolic compounds determination in the aqueous extract of M. guianensis (AEMg) and hidroalcoholic extract (HEMg).

\begin{tabular}{ccccc}
\hline $\begin{array}{c}\text { Phenolic } \\
\text { compounds }\end{array}$ & \multicolumn{2}{c}{ AEMg } & \multicolumn{2}{c}{ HEMg } \\
\hline & $25^{\circ} \mathrm{C}$ & $70^{\circ} \mathrm{C}$ & $60 \%$ & $70 \%$ \\
\hline $\begin{array}{c}\text { Total phenolics } \\
\text { (gTAE } / 100 \mathrm{~g})\end{array}$ & $0.19 \pm 0.00$ & $20.85 \pm 1.09$ & $1.15 \pm 0.01$ & $1.10 \pm 0.07$ \\
$\begin{array}{c}\text { Total tannins } \\
\text { (gTAE } / 100 \mathrm{~g})\end{array}$ & $0.38 \pm 0.01$ & $16.37 \pm 1.71$ & $1.52 \pm 0.01$ & $1.46 \pm 0.01$ \\
$\begin{array}{c}\text { Total flavonoids } \\
\text { (gRE } / 100 \mathrm{~g})\end{array}$ & $0.05 \pm 0.00$ & $0.45 \pm 0.10$ & $0.09 \pm 0.00$ & $0.07 \pm 0.00$ \\
\hline
\end{tabular}

$\mathrm{TAE}=$ tannic acid equivalent; $\mathrm{RE}=$ Rutin equivalent. Results expressed as mean \pm Standard deviation $(\mathrm{n}=3)$.

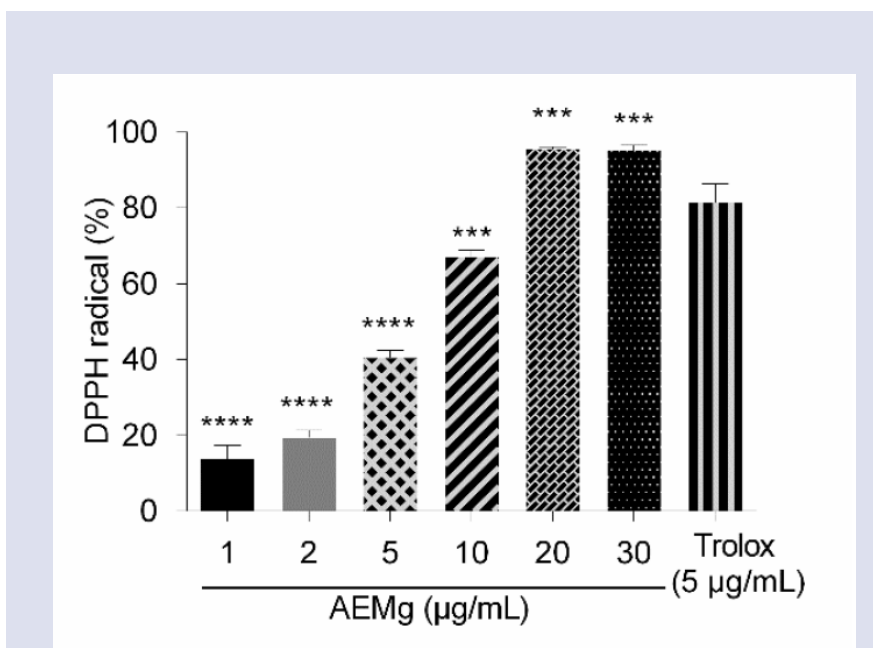

Figure 1: Antioxidant activity of the aqueous extract of $M$. guianensis (AEMg) and Trolox $(5 \mu \mathrm{g} / \mathrm{mL})$, conducted by the DPPH radical scavenging assay. Results expressed as mean \pm standard deviation $(n=3)$. Statistical difference compared to Trolox. ${ }^{* * *}=p<0,001$ and **** $p<0,0001$.

The contents of phenolic compounds in AEMg and HEMg are listed in Table 2. The AEMg, elaborated at $70^{\circ} \mathrm{C}$, was more efficient, presenting more significant values for phenols, tannins and flavonoids. Concerning $\mathrm{HEMg}$, it was observed that there was no significant difference between the extraction methods, using $60 \%$ and $70 \%$ ethanol. These results are compatible with the traditional use of $M$. guianensis, whose leaves are used as hypoglycemic and antihemorrhagic. Therefore, the temperature of $70^{\circ} \mathrm{C}$ used for the tea preparation seems to be an essential factor for more efficient extraction, particularly of the phenolic compounds.

\section{Antioxidant capacity of the aqueous extract of $M$. guianensis (AEMg) DPPH radical scavenging}

The reaction of the AEMg with the DPPH radical was conducted for $90 \mathrm{~min}$ and showed stability in the percentage of inhibition (I \%) at 45 min of reaction, achieving a mean of $95 \%$ inhibition at concentrations of 20 and $30 \mu \mathrm{g} / \mathrm{mL}$. The percent inhibition (I \%) of the Trolox standard $(5 \mu \mathrm{g} / \mathrm{mL})$ was $83.4 \%$, at the same reaction time. The concentration of AEMg capable of reducing $50 \%$ of DPPH $\left(\mathrm{IC}_{50}\right)$ was $7.9 \mu \mathrm{g} / \mathrm{mL}$ and for Trolox was $3.0 \mu \mathrm{g} / \mathrm{mL}$, evidencing a high antioxidant potential of the AEMg for this assay (Figure 1). 


\section{$\beta$-carotene/linoleic acid assay}

The $\beta$-carotene bleaching method, which analyzes the degree of inhibition of lipid peroxidation of linoleic acid, is shown in Figure 2. The AEMg and Trolox were found to have stability at all absorbance measurements over the time of reaction and inhibition of the $\beta$-carotene consumption, resulting to high values in the percent inhibition of AEMg (92.0\%) and Trolox (81.4\%), respectively. Therefore, the AEMg also presents a significant antioxidant activity against the radicals generated during the peroxidation of linoleic acid and $\beta$-carotene bleaching.

\section{FRAP assay}

The antioxidant activity of the aqueous extract of M. guianensis, performed by the ferric ion reduction test (FRAP), was estimated by its ability to reduce the complex TPTZ-Fe (III) to TPTZ-Fe (II). The reaction led to the formation of an intense blue color, which was analyzed by UV-Visible spectrophotometry. The results showed that the absorbance values at $593 \mathrm{~nm}$ intensify as a function of the increased production of the TPTZFe (II) complex, as well as with the increase of the AEMg and Trolox concentration, the latter used as the standard (Figure 3).

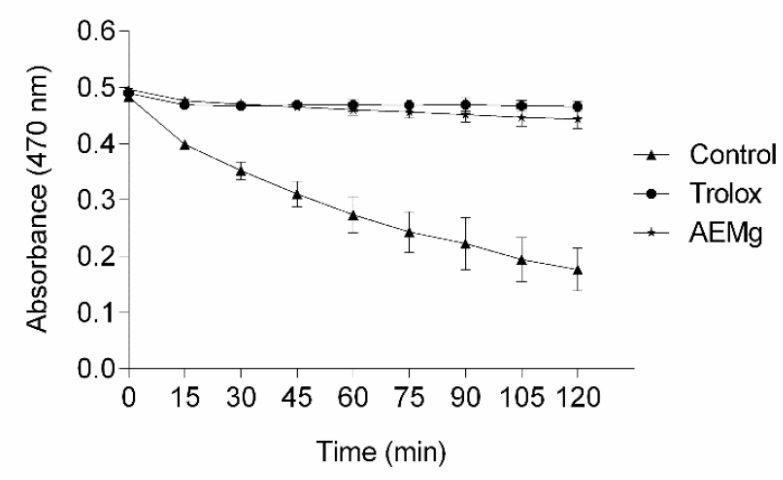

Figure 2: Antioxidant activity of the aqueous extract of $M$. guianensis (AEMg) and Trolox, performed by the $\beta$-carotene/linoleic acid assay. Results expressed as mean \pm standard deviation $(n=3)$.

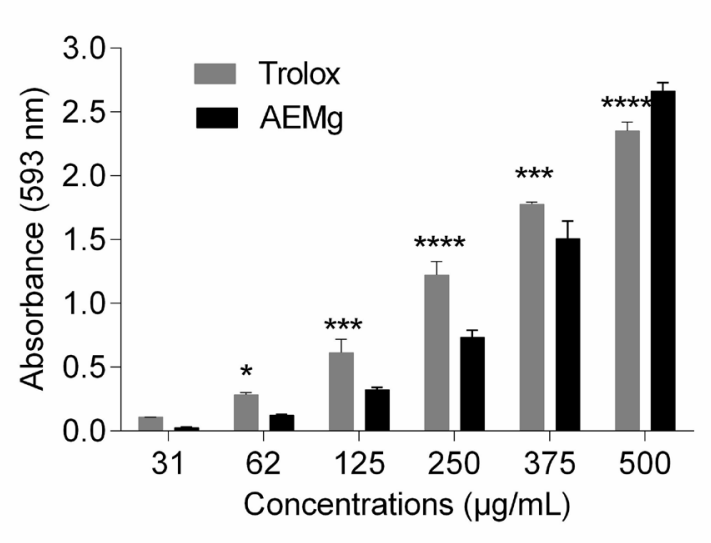

Figure 3: Antioxidant activity of the aqueous extract of $M$. guianensis (AEMg) and Trolox, performed by the FRAP assay. Results expressed as mean \pm standard deviation $(n=3)$. Statistical difference compared to Trolox. ${ }^{*}=p<0,05 ;{ }^{* * *}=p<0,001$ and ${ }^{* * * *} p<0,0001$.
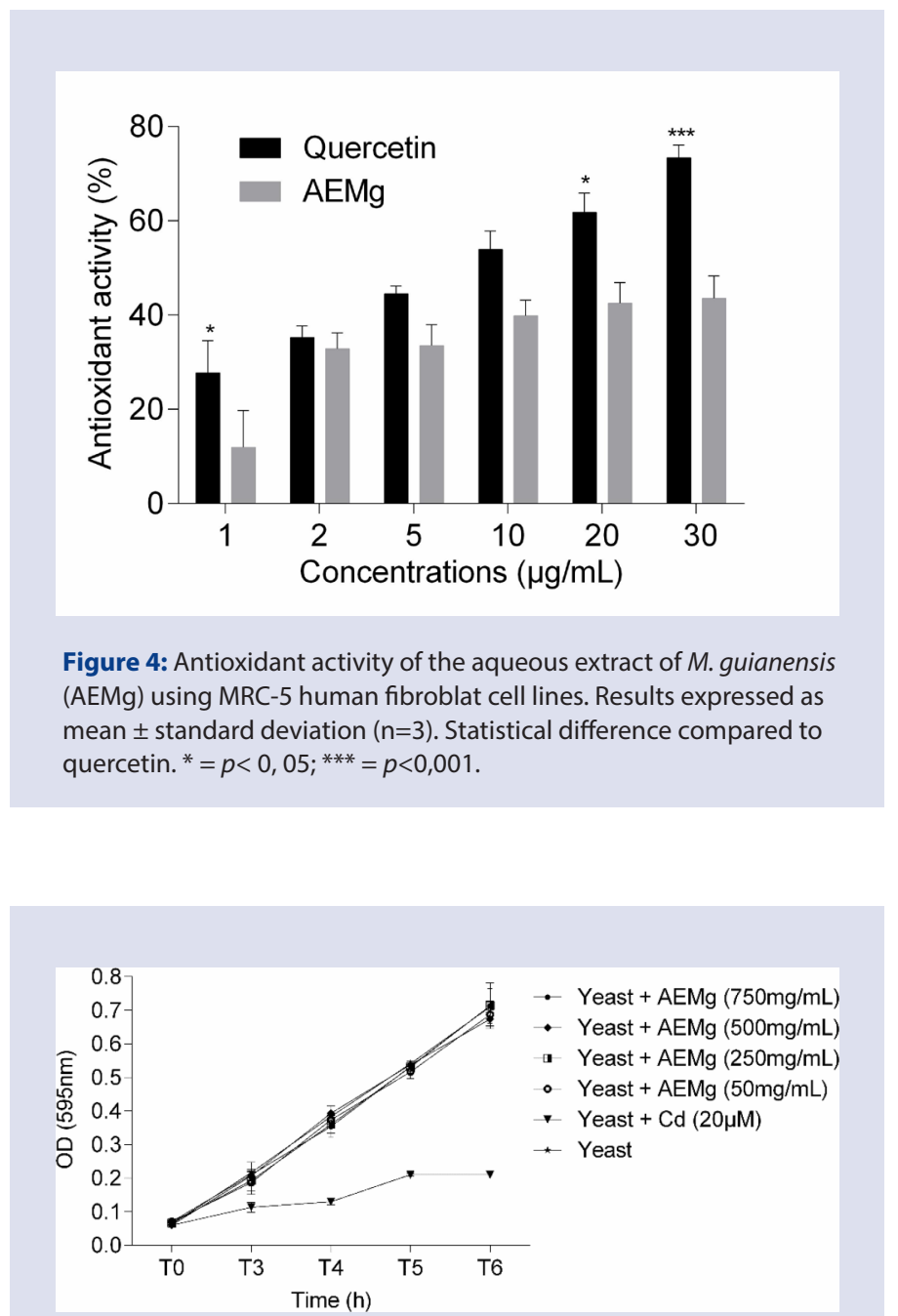

Figure 5: Growth curve of Saccharomyces cerevisiae in the presence of aqueous extract of $M$. guianensis (AEMg) and cadmium to determine its cytotoxic effects. Results expressed as mean \pm standard deviation $(n=3)$.

\section{Human cell culture assay}

According to the results of antioxidant activity in human fibroblast cells, depicted in Figure 4, AEMg exhibited antioxidant activity at all concentrations tested. These results were compared with the quercetin standard, with a statistical difference at only $1.0 \mu \mathrm{g} / \mathrm{mL}$ (about $12.0 \%$ inhibition). A dose-response pattern was not observed in the AEMg assay, since starting from the concentration of $10 \mu \mathrm{g} / \mathrm{mL}$, the percent inhibition did not show a significant difference. Therefore, in the human fibroblast cells assays, the use of concentration above $10.0 \mu \mathrm{g} / \mathrm{mL}$ is not required. The percentual inhibition of AEMg was $39.8 \%$ at the concentration of $10.0 \mu \mathrm{g} / \mathrm{mL}$, close to the quercetin value (53.9\%), at the same concentration.

\section{Cytotoxicity of the aqueous extract of M. guianensis (AEMg)}

AEMg did not show cytotoxicity against Saccharomyces cerevisiae eukaryotic cells at concentrations of 50 to $750 \mathrm{mg} / \mathrm{mL}$, during the assay (6 h) (Figure 5). The result was compared to a cadmium assay, this later used as a cytotoxic agent that, conversely, inhibited yeast growth by over 
$70 \%$. The exponential growth of yeasts in the presence of AEMg occurred similarly to the yeasts maintained only in the culture medium, showing that the components present in AEMg are not toxic to cell growth.

Likewise, in the cytotoxicity assay with PBMC, concentrations 1, 10, 50, 100 and $200 \mu \mathrm{g} / \mathrm{mL}, \mathrm{AEMg}$ was also shown to be non-toxic to human blood cells. The $\mathrm{IC}_{50}$ value was above $200 \mu \mathrm{g} / \mathrm{mL}$.

\section{DISCUSSION}

In recent years, there has been considerable interest in the use of medicinal plants in third world countries, particularly in Latin America and the Amazon region, for their richness and floristic diversity. Also, a large part of the native population, especially those that are far from the big urban centers, has little access to the public health system, making the use of medicinal plants the only form of treatment or the relief of diseases. On the other hand, although many species have been used for many years in the treatment of several diseases, most of these plants still do not present studies that can subsidize their popular use or even conduct them to the production of new plant drugs for phytotherapeutic activities and under the control of the sanitary surveillance of these countries and Myrcia guianensis is a good example.

Phenolic compounds content and antioxidant activity are parameters of quality for tea pertaining to its biological properties. ${ }^{28}$ The preparation of the AEMg at $70^{\circ} \mathrm{C}$ proved to be the most efficient methodology for the extraction of phenolic compounds, some previously identified in the plant, such as gallic, tannic, quinic and protocatechuic acids, as well as other glycosylated flavonoid derivatives. ${ }^{12-13}$ These phenolic compounds, present in several fruits and vegetables, have been described as potent natural antioxidants, capable of eliminating reactive oxygen species (ROS). Most probably, the high antioxidant capacity observed in the aqueous extract of $M$. guianensis and highlighted here in the tests conducted with the DPPH radical, the $\beta$-carotene/linoleic acid system and the reduction of the ferric ion (FRAP), is due to the presence of these phenolic compounds. They were also previously quantified by the spectrophotometric analysis with the use of ferric and aluminum chloride. In addition, these results justify the extractive methodology using water as the solvent which, in addition to being simpler, faster, more efficient and non-toxic, still could promote an active extraction of phenolic compounds identified in the plant. ${ }^{29-30}$

The antioxidant activity of the AEMg was also evidenced in the human fibroblast cell assay when analyzing the intracellular production of ROS, detected by cell-permeant reagent DCFDA, which is an indicator of oxidative stress. ${ }^{31}$ The results showed that the AEMg presented a significant antioxidant activity against ROS generated by hydrogen peroxide. The percentage of inhibition of ROS in the presence of AEMg was similar to that found for the quercetin standard, especially at the lower concentrations $(2,5$ and $10 \mu \mathrm{g} / \mathrm{mL})$, where there was no statistical difference between treatments.

Cytotoxicity assays with eukaryotic cells shown the absence of toxic components in the AEMg leaves, suggesting preliminarily that their consumption in the tea form does not cause deleterious or damaging effects to the human being. Toxicological studies with medicinal plant extracts are important and necessary to assess the quality, efficacy and, above all, their safety. Another aspect addressed in this study is the discovery and establishment of natural antioxidants that can protect the human body against harmful damage caused by constant exposure to free radicals, as well as prevent the spread of many chronic diseases. ${ }^{32}$

\section{CONCLUSION}

The results of this study confirm the relationship between the phenolic compounds content of the aqueous extract of the leaves of M. guianensis and its antioxidant capacity, which was determined by different methodologies. The cytotoxic assays carried out indicate that tea from the leaves of M. guianensis does not present harmful components to its traditional use as a hypoglycemic and anti-hemorrhagic agent or as a new source of natural antioxidant. However, it is still necessary to carry out studies with in vivo models to better ensure their phytotherapeutic efficacy and safety.

\section{ACKNOWLEDGEMENT}

The authors would like to thank CAPES, CNPq and FAPESPA, the Brazilian and Pará Government's research funding agencies, for their financial support.

\section{CONFLICT OF INTEREST}

The authors declare no conflict of interest.

\section{ABBREVIATIONS}

AEMg: Aqueous Extract of M. guianensis; DPPH: 2,2-diphenyl-1-picrylhydrazyl; FRAP: Ferric Reducting Ability of Plasma; ROS: reactive oxygen species; PBMC: Peripheral Blood Mononuclear Cells; INPA: Instituto Nacional de Pesquisas da Amazônia; TROLOX: 6-hydroxy2,5,7,8-tetramethylchromane-2-carboxylic acid; TPTZ: 2,4,6-tris(2pyridyl)-1,3,5-triazine; DMEM: Dulbecco's Modified Eagle's Medium; PBS: Phosphate Buffered Saline; DCFDA: 2', 7'-Dichlorofluorescin diacetate; YPD: Yeast Extract-Peptone-Dextrose; MTT: 3-(4,5-dimethylthiazol-2-yl)-5-diphenyltetrazolium bromide; SDS: Sodium Dodecyl Sulfate.

\section{REFERENCES}

1. Govaerts R, Sobral M, Ashton P, Barrie F, Holst BK, Landrum LL, et al. World checklist of Myrtaceae. Kew: Kew Publishing, Kew Royal Botanic Gardens. 2008.

2. Landrum LR, Kawasaki ML. The genera of Myrtaceae in Brazil: An illustrated synoptic treatment and identification keys. Brittonia. 1997;49(4):508-36.

3. Sobral M, Proença C, Souza M, Mazine F, Lucas E. Myrtaceae. Lista de espécies da flora do Brasil. Rio de Janeiro: Jardim Botânico do Rio de Janeiro. 2015. [update 2017 December]. Available from: http://floradobrasil.jbrj.gov.br.

4. Lucas EJ, Matsumoto K, Harris SA, Nic Lughadha EM, Benardini B, Chase MW. Phylogenetics, morphology and evolution of the large genus Myrcia sl. (Myrtaceae). International Journal of Plant Science. 2011;172(7):915-34.

5. Missouri Botanical Garden. 2017. [update 2017 December]. Available from: www.tropicos.org/Name/22103038.

6. Yoshikawa M, Shimada H, Nishida N, Li Y, Togushida I, Yamahara J, et al. Antidiabetic principles of natural medicines. II. Aldose reductase and $\alpha$-glucosidase inhibitors from Brazilian natural medicine, the leaves of Myrcia multiflora DC. (Myrtaceae): Structures of Myrciacitrins I and II and Myrciaphenones A and B. Chemical and Pharmaceutic Bulletin. 1998;46(1):113-9.

7. Matsuda H, Nishida N, Yoshikawa M. Antidiabetic principles of natural medicines. $\checkmark$ Aldose reductase inhibitors from Myrcia multiflora DC. (2): Structures of Myrciacitrins III, VI and V. Chemical Pharmaceutical Bulletin. 2002;50(3):429-31.

8. Vareda PM, Saldanha LL, Camaforte NA, Violato NM, Dokkedal AL, Bosqueiro JR. Myrcia bella leaf extract presents hypoglycemic activity via PI3k/Akt insulin signaling pathway. Evidence-Based Complementary and Alternative Medicine. 2014. doi:10.1155/2014/543606.

9. Moresco HH, Pereira M, Bretanha LC, Micke GA, Pizzolatti MG, Brighente IM Myricitrin as the main constituent of two species of Myrcia. Journal of Applied Pharmaceutical Science. 2014;4(2):1-7.

10. Wubshet SG, Moresco HH, Tahtah Y, Brighente IM, Staerk D. High-resolution bioactivity profiling combined with HPLC-HRMS-SPE-NMR: $\alpha$-Glucosidase inhibitors and acetylated ellagic acid rhamnosides from Myrcia palustris DC. (Myrtaceae). Phytochemistry. 2015;116:246-52. doi:10.1016/j.phytochem.2015.04.004

11. Sousa LA, Moura VM, Raposo JD, Sousa LF, Oliveira RB, Santos LS, et al. The effect of the aqueous extract of Myrcia guianensis (Aubl.) DC. And its fractions against the hemorrhagic activity of Bothrops jararaca venom. Journal of Medicinal Plants Research. 2013;7(42):3139-46. doi:0.5897/JMPR2013.5119.

12. Franco DM, Saldanha LL, Silva EM, Nogueira FT, Dokkedal AL, Santos $C$, et al. Effects of leaf extracts of Myrcia guianensis (Aubl.) DC. On growth and gene expression during root development of Sorghum bicolor (L.) Moench. Allelopathy Journal. 2015;35(2):237-48. 
13. Souza FAP, Santos RA, Santos LS, Guilhon GM, Santos AS, Arruda MS, et al. Allelophatic potencial of Myrcia guianensis. Planta Daninha. 2006;24(4):649-56

14. Saldanha LL, Vilegas W, Dokkedal AL. Characterization of flavonoids and phenolic acids in Myrcia bella Cambess. With FIA-ESI-IT-MS and HPLC-PAD-ESI-IT-MS combined with NMR. Molecules. 2013;18(7):8402-16.

15. Cascaes MM, Guilhon GM, Andrade EH, Zoghbi MG, Santos LS. Constituents and pharmacological activities of Myrcia guianensis (Aubl.) DC: A review of an aromatic and medicinal group of plants. International Journal of Molecular Sciences. 2015;16(10):23881-904. doi:10.3390/ijms161023881.

16. Noori S. An overview of oxidative stress and antioxidant defensive system. Open Access Scientific Reports. 2012;1(8):1-9.

17. Scalbert A, Williamson G. Dietary intake and bioavailability of plyphenols. Journal of Nutrition. 2000;130(8):2073-85.

18. Tung YT, Wu JH, Kuo YH, Chang ST. Antioxidant activities of natural phenolic compounds from Acacia confuse bark. Bioresource Technology. 2007;98(5):1120-3.

19. Farmacopeia B. Brasília: Agencia Nacional de Vigilância Sanitária. ANVISA. 2010;546.

20. Hagerman AE, Butler LG. Protein precipitation method for the quantitative deter mination of tannins. Journal of Agricultural and Food Chemistry. 1978;26(4):809-12.

21. Chabariberi RA, Pozzi AC, Zeraik ML Yariwake JH Spectrometric determination of flavonoids from Maytenus (Celastraceae) and Passiflora (Passifloraceae) leaves and comparison with an HPLC-UV method. Brazilian Journal of Pharmacognosy. 2009;19(4):860-4.

22. Miliauskas G, Venskutonis PR, Van BTA. Screening of radical scavenging activity of some medicinal and aromatic plant extracts. Food Chemistry. 2004;85(2):231-7. doi:10.1016/j.foodchem.2003.05.007.

23. Koleva II, Van BT, Linssen JP, De Groot A, Evstatieva LN. Screening of plant extracts for antioxidant activity: A comparative study on three testing methods.
Phytochemical Analysis. 2002;13(1):8-17. doi:10.1002/pca.611.

24. Pishoschi AM, Negulescu GP. Methods for total antioxidant activity determination: A review. Biochemistry and Analytical Biochemistry. 2011;1(1):1-6. doi:10.4172/2161-1009.1000106

25. Wolfe, KL, Liu RH. Celular antioxidant activity (CAA) assay for assessing antioxidants, foods and dietary supplements. J Agric Food Chem. 2007;55(22):8896-907.

26. Sherman F. Getting started with yeast. Methods in Enzymology. 2002;350:3-41.

27. Campos JF, Pereira MC, De Sena WL, Martins CG, De Oliveira JF, Amorim CA, et al. Synthesis and anticancer in vivo activity of new 2-thioxo-oxazalidin-4-one derivatives. Pharmacological Reports. 2017;69:633-41. doi:10.1016/j.pharep. 2017.03.005.

28. Anesini C, Ferraro GE, Filip R. Total polyphenol content and antioxidant capacity of commercially available tea (Camellia sinensis) in Argentina. Journal of Agricultural and Food Chemistry. 2008;56(19):9225-9.

29. Dai J, Mumper RJ. Plant phenolics: Extraction, analysis and their antioxidant and anticancer properties. Molecules. 2010;15(10):7313-52. doi:10.3390/molecules 15107313.

30. ColomeuTC, Figueiredo D, Cazarin CB, Schumacher NS, Maróstica MR, Meleti LM, et al. Antioxidant and anti-diabetic potential of Passiflora alata Curtis aqueous leaves extract in type 1 diabetes mellitus (NOD-mice). International Immunopharmacology. 2014;18(1):106-15. doi:10.1016/j.intimp.2013.11.005

31. Karakas FP, Turker AU, Karakas A, Mshvildadze V, Pichette A, Legault J. In vitro cytotoxic, antibacterial, anti-inflammatory and antioxidant activities and phenolic content in wild-grown flowers of common daisy - A medicinal plant. Journal of Herbal Medicine. 2017;8:31-9. doi:10.1016/j.hermed.2016.11.003.

32. Rodríguez-Chávez JL, Coballase-Urrutia E, Sicilia-Argumedo G, Ramírez-Apan T, Delgado $G$. Toxicological evaluation of the natural products and some semisynthetic derivates of Heterotheca inuloides Cass (Asteraceae). Journal of Ethnopharmacology. 2015;175:256-65. doi:10.1016/j.jep.2015.08.055

\section{GRAPHICAL ABSTRACT}

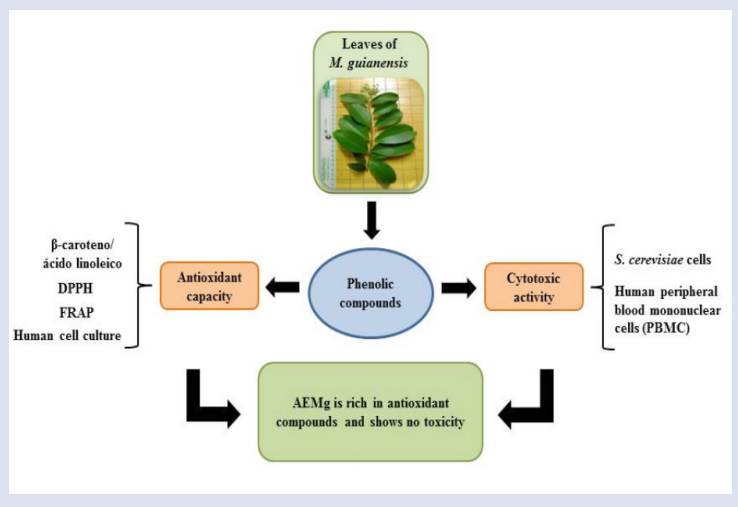

\section{SUMMARY}

- Present study was done to explore the antioxidant capacity and the cytotoxicity of the aqueous extract of the leaves of M. guianensis (AEMg). After determination of the phenolic compounds, the antioxidant capacity was tested by different methods: sequestration of DPPH radicals, $\beta$-carotene bleaching, ferric ion reduction potential (FRAP) and in human fibroblast cells of the MRC-5 lineage. The cytotoxic of AEMg was evaluated in assays with eukaryotic cells from yeast Saccharomyces cerevisiae and in PBMC. AEMg is rich in phenolic compounds, presenting high antioxidant potential in all the tests carried out, besides not being toxic to eukaryotic cells. The AEMg, rich in antioxidant compounds and no toxicity, can be used as natural alternative source in the treatment of metabolic diseases to combat free radicals.

Cite this article: Bernardes RSA, Sarrazin SLF, Santos FA, Rêgo MJBM, Pitta MGR, Cordeiro MF, Almeida PDO, Oliveira RB, Bouillet LÉM, Maia JGS, Mourão RHV. Antioxidant Capacity and Cytotoxicity of the Aqueous Extract of Myrcia guianensis (Aubl.) DC. Pharmacog J. 2018;10(6)Suppl:s135-s140. 